Journal of Environmental Science and Sustainable Development

7-31-2019

\title{
FRACTIONATION OF IRON (Fe) AND MANGANESE (Mn) IN THE HORIZONS OF A FOREST SOILS, AGROFORESTRY, AND DRYLAND AGRICULTURE
}

Parjono Parjono

Agriculture Engineering, Musamus University, parjonotp@gmail.com

Syaiful Anwar

Departement of Soil Science and Resources, Bogor Agriculture University

Kukuh Murtilaksono

Departement of Soil Science and Resources, Bogor Agriculture University

Lilik Indriyati

Departement of Soil Science and Resources, Bogor Agriculture University

Follow this and additional works at: https://scholarhub.ui.ac.id/jessd

Part of the Environmental Studies Commons

\section{Recommended Citation}

Parjono, Parjono; Anwar, Syaiful; Murtilaksono, Kukuh; and Indriyati, Lilik (2019). FRACTIONATION OF IRON (Fe) AND MANGANESE (Mn) IN THE HORIZONS OF A FOREST SOILS, AGROFORESTRY, AND DRYLAND AGRICULTURE. Journal of Environmental Science and Sustainable Development, 2(1), 117-126. Available at: https://doi.org/10.7454/jessd.v2i1.32

This Review Article is brought to you for free and open access by the School of Environmental Science at UI Scholars Hub. It has been accepted for inclusion in Journal of Environmental Science and Sustainable Development by an authorized editor of UI Scholars Hub. 


\title{
FRACTIONATION OF IRON (Fe) AND MANGANESE (Mn) IN THE HORIZONS OF FOREST SOILS, AGROFORESTRY, AND DRYLAND AGRICULTURE
}

\author{
Parjono $^{1, *}$, Syaiful Anwar ${ }^{2}$, Kukuh Murtilaksono ${ }^{2}$, and Lilik Indriyati² \\ ${ }^{1}$ Agriculture Engineering, Musamus University, Merauke, Papua 99611, Indonesia \\ ${ }^{2}$ Departement of Soil Science and Resources, Bogor Agriculture University, Bogor, West \\ Java 16680, Indonesia
}

*Corresponding author: e-mail: parjonotp@gmail.com

(Received: 11 June 2019; Accepted: 25 July 2019; Published: 31 July 2019)

\begin{abstract}
One of the main problems with acidic soils is the availability of soil nutrients. In such soils, iron (Fe) and manganese (Mn) ions are highly present. This study evaluated the Fe and $\mathrm{Mn}$ fractions in the soil profiles of forests used for agroforestry and dryland agriculture in the upper Ciliwung watershed. The watershed is a zone of high rainfall washing. The evaluation was based on the results of analysis of soil samples taken at four soil horizons (Ao or Ap, A1 or A2, B1, and B2) for each type of land use. Research was conducted by survey and laboratory analysis. Fractionation of Fe and Mn employed sequential extraction methods with different compounds in each fraction. Fractionation was divided into exchangeable fractions (Exch), acid extractable (Acex), can be reduced (Red), oxidized (Oxs), and residual (Res). Results showed that Res Fe was (>23000.8 ppm or 76.3\%) and Oxs Mn (>1642.9 ppm or 52.9\%) dominated each type of land use, while the lowest fractions were Exch Fe $(<12.2 \mathrm{ppm}$ or $0.022 \%$ ) and Exch Mn fraction ( $<97.2 \mathrm{ppm}$ or $1.50 \%)$ in each type of land use.
\end{abstract}

Keywords: extraction; fraction; land use; leaching; profiles

\section{Introduction}

Land use changes in watershed areas cause dissolution and leaching of nutrients and organic carbon downstream. Accumulation of leached nutrients from soils and solutions result in pollution of water bodies and land degradation, disrupting the balance of ecosystems with a measurable impact on people's lives. Nutrient losses due to leaching can occur under the cover of vegetated lands such as forests, plantations, and agricultural land. Iron ( $\mathrm{Fe}$ ) and manganese $(\mathrm{Mn})$ are micronutrients essential to plant life. Iron plays a role in the metabolic processes of plants, such as photosynthesis and respiration, and is the main constituent of cell proteins (Celik, Asik, Gurel, \& Katkat, 2010; Mehraban, Ahmad, \& Hamid, 2008). Lack of $\mathrm{Fe}$ and Mn causes deficiencies in micronutrients, while excessive amounts are toxic to plants.

$\mathrm{Mn}$ is unstable in the oxide-reducing conditions of soils. The oxidation process of $\mathrm{Mn}^{2+}$ causes immobilization of $\mathrm{Mn}$, and the process of reducing $\mathrm{Mn}^{3+}$ and $\mathrm{Mn}^{4+}$ causes immobilization of $\mathrm{Mn}$ as it dissolves in the soil solution. Weathered soil with hydroxide compounds in clay mineral complexes such as Al-hydroxide will release $\mathrm{Al}^{3+}$ ions into the soil solution. This will meet with water to produce soil acidity $\left(\mathrm{H}^{+}\right)$, so that $\mathrm{Mn}$ oxide is 
reduced. Increased solubility of $\mathrm{Mn}^{2+}$ at low $\mathrm{pH}$ causes plant toxicity (Ghiorse, 1988). Total $\mathrm{Mn}$ in soil of about 200 to 3,000 ppm averaging $600 \mathrm{mg} / \mathrm{kg}$ has the same properties as alkali metals such as $\mathrm{Zn}$ and $\mathrm{Fe}$. The divalent form of $\mathrm{Mn}$ is bound by clay minerals and organic matter, while its tetravalent ion in oxide form is sometimes associated with ferry-oxide concretions (Russel \& Sir, 1978).

Tessier, Campbell, \& Bisson (1979) and Walna, Spychalski, \& Ibragimow (2010) classified the elements $\mathrm{Fe}$ and $\mathrm{Mn}$ into several fractions, i.e.: (1) fractions exchangeable (Exch), to estimate the availability of Fe and $\mathrm{Mn}$ in soil, (2) acid extractable fraction (Acex), to estimate carbonate-bound or marginally available metal forms for plants, (3) oxidizable (Oxs), to estimate completely decomposed material attached to various components of soil minerals or those less available for plants, (4) reducible (Red), to estimate dissolution of amorphous minerals at lower levels, crystalline oxides, or very poor availability for plants (Abollino et al., 2006), and (5) residual fractions (Res), to estimate crystalline minerals that are very stable and not available to plants. Mobility factors were calculated based on the sum of all Fe and Mn fractions, except the residual fraction (Sutherland, 2002). Residual fractions were found to be the most stable crystals and are not available to plants (Tessier et al., 1979; Wang et al., 2008).

Generally, $\mathrm{Fe}$ in soils is in the form of ferri $\left(\mathrm{Fe}^{3+}\right)$ and ferro $\left(\mathrm{Fe}^{2+}\right) . \mathrm{Fe}^{3+}$ is mobile, while $\mathrm{Fe}^{2+}$ is immobilized in $\mathrm{Fe}(\mathrm{OH})^{3-}$. Fe can be spread evenly or concentrated to form certain morphological media such as soil rust, patches, or concretions. Release of Fe from silicate minerals forms $\mathrm{Fe}^{3+}$. Iron-free [silicate?] can be immediately oxidized or carried away by the flow of water when there is oxygen; when in contact with water, it will be hydrolyzed to $\mathrm{Fe}^{3+}$ (Segalen, 1971). Land use and soil acidity due to heavy, continuous rainfall causes variability in the concentration and availability of $\mathrm{Fe}$ and $\mathrm{Mn}$ in the soil profile. To achieve sustainable agriculture, it is necessary to study the distribution of Fe and Mn under different land uses such as forestry, agroforestry, and dryland agriculture for improved management.

\section{Methods}

\subsection{Time and Place}

This research was conducted from May 2016 to April 2017. Samples of soil were taken in Cisarua District, Bogor Regency, West Java, in the upstream area of the Ciliwung watershed in forested, agro-forested, and dryland agricultural land. Forested land was located at $6^{\circ} 69^{\prime} 443^{\prime \prime} \mathrm{LS}$ and $106^{\circ} 98^{\prime} 889^{\prime \prime B T}$, agroforestred at $6^{\circ} 69^{\prime} 737^{\prime \prime} \mathrm{LS}$ and $106^{\circ} 97^{\prime} 673^{\prime \prime} \mathrm{BT}$, and dryland agricultural at $6^{\circ} 69^{\prime} 530^{\prime \prime} \mathrm{LS}$ and $106^{\circ} 98^{\prime} 726^{\prime \prime} \mathrm{BT}$. Analysis of soil physical and chemical properties was carried out at the Laboratory of Chemical and Soil Fertility, Department of Soil Science and Land Resources (DITSL), Faculty of Agriculture, Bogor Agricultural University (IPB).

\subsection{Materials and Method}

Soil samples in this study were analyzed in the laboratory untreated. Fractionation of Fe and Mn was carried out using the method of Tessier et al. (1979) \& Walna et al. (2010); soil pH $\left(\mathrm{H}_{2} \mathrm{O}\right.$ and $1 \mathrm{M} \mathrm{KCl}$ ), organic $\mathrm{C}$ (Walkey and Black), and soil texture (piping) (Eviati \& Sulaeman, 2010) were recorded. Data analysis was conducted through graphs and tables 
using Microsoft Office Excel 2013. Fractionation procedures of Fe and Mn are presented in Table 1.

Table 1. Fractionation procedure of Fe and Mn Tessier et al. (1979) and Walna et al. (2010)

\begin{tabular}{|c|c|c|c|c|}
\hline $\begin{array}{c}\text { Observation } \\
\text { parameter }\end{array}$ & Chemical & Temperature & pH & $\begin{array}{l}\text { Shaker } \\
\text { (Hour) }\end{array}$ \\
\hline $\begin{array}{l}\text { Exchangeable (Exch } \\
\text { Fe/Mn) }\end{array}$ & 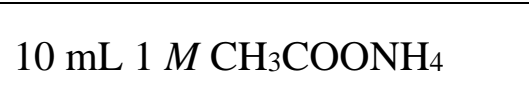 & Room & 7.0 & 1 \\
\hline $\begin{array}{l}\text { Acid extractable (Acex } \\
\text { Fe/Mn) }\end{array}$ & $20 \mathrm{~mL} 1 M \mathrm{CH}_{3} \mathrm{COONa}$ & Room & 5.0 & 5 \\
\hline Reduksi (Red Fe/Mn) & $\begin{array}{l}20 \mathrm{~mL} 0.04 M \mathrm{NH}_{2} \mathrm{OH} . \mathrm{HCl} \text { in } \\
25 \% \mathrm{CH}_{3} \mathrm{COOH}\end{array}$ & $96^{\circ} \mathrm{C}$ & & 5 \\
\hline \multirow{3}{*}{$\begin{array}{l}\text { Oksidizible (Oxs } \\
\text { Fe/Mn) }\end{array}$} & $\begin{array}{l}5 \mathrm{~mL} 0.02 M \mathrm{HNO}_{3}+5 \mathrm{~mL} \\
30 \% \mathrm{H}_{2} \mathrm{O}_{2}\end{array}$ & $85^{\circ} \mathrm{C}$ & 2.0 & 2 \\
\hline & 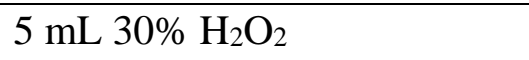 & $85^{\circ} \mathrm{C}$ & 2.0 & 3 \\
\hline & 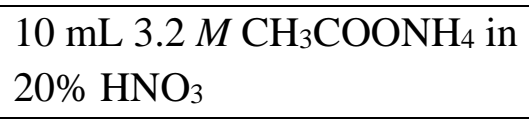 & Room & & 0.5 \\
\hline Residual (Res Fe/Mn) & $\begin{array}{l}2 \mathrm{~mL} \mathrm{HClO}_{4}+10 \mathrm{~mL} \mathrm{HF} \\
\text { evaporated to dry }+6 \mathrm{M} \mathrm{HCl}\end{array}$ & $96^{\circ} \mathrm{C}$ & & 12 \\
\hline
\end{tabular}

\subsection{Research Procedure}

The research location was determined based on overlaying a map of soil types and land cover. Two soil profiles, each $5 \mathrm{~m}-10 \mathrm{~m}$ apart, were taken from each land use zone on the central slope at a slope of $16^{\circ}-35^{\circ}(30 \%-70 \%)$ (Figure 1). Profiles were made by excavation to the soil's solum boundary, sized $1 \mathrm{~m}$ x $1 \mathrm{~m}$ x $1.5 \mathrm{~m}$. Samples of disturbed soil were taken at amounts of up to $500 \mathrm{~g}$ from four soil horizons. Each profile was used for analysis of soil texture and Fe and Mn fractions. Samples were then put into ethylene plastic bags, labeled, and stored in a cooler for soil analysis in the laboratory. Analysis of Fe and Mn fractions in the soils used the method of Tessier et al. (1979) and Walna et al. (2010) (Table 1)

\subsection{Sequential Extraction}

Sequential extraction was used to evaluate the Fe and Mn fractions in the soils (Tessier et al., 1979, and Walna et al., 2010) (Table 1). Extraction was carried out using a $50 \mathrm{~mL}$ centrifugal test tube. Samples were then shaken using a horizontal shaker equipped with a water thermostat set to $20^{\circ} \mathrm{C}-100^{\circ} \mathrm{C}$ with an accuracy of $\pm 2^{\circ} \mathrm{C}$. Surfactant was transferred into a polypropylene test tube. The original solid was washed with $5 \mathrm{~mL}$ distilled water, centrifuged for $30 \mathrm{~min}$ at a speed of 2,500 rpm, and drained of all liquid. This was repeatedly carried out until the residual fraction stage. Surfactant polypropylene was analyzed using an Atomic Absorption Spectrophotometer brand SHIMADZU type AA-6300 with a wavelength of 248.3 $\mathrm{nm}$ for Fe and $279.5 \mathrm{~nm}$ for Mn. Fraction extraction was then carried out using the fraction residual solids. The solution was immersed in concentrated nitric acid to obtain a $\mathrm{pH}$ between 5.0 and 2.0 for further extraction. Extraction (Tessier et al., 1979) could not reach the residual fraction stage, so $\mathrm{HClO}_{4}$ and $\mathrm{HF}$ acids were used to reach the residual stage. 


\section{Results and Discussion}

\subsection{Nature of the Soils at the Research Location}

Distributions of the nature of the land profiles and horizons in the forested, agro-forested, and dryland agriculture zones are presented in Table 2. Land in each land use zone was classified as inceptisol with an acidic to very acidic character. Each land horizon in the forested land was dominated by dusty sand fractions, the agroforestry land by sandy dust fraction, and the dryland agricultural surface by sandy and dusty fractions both at and beneath the surface. Of the three zones, the forested land had the highest organic matter content. Intensity of land processing played an important role in the distribution of organic matter in the soils. Mineralogical composition showed that each soil horizon in the forested and dryland agricultural lands was dominated by fractions of sand and clay. Main sources of Fe and Mn came from amorphous oxides, crystalline oxides, and hydroxides from clay minerals such as illite or smectite and vermiculite. Vermiculite is a clay mineral that releases Fe ions in acidic soils (Dubikova, Cambier, Sucha, \& Caplovicova, 2002).

Table 2. Nature of soils in the forested, agro-forested, and dryland agricultural zones in the research location

\begin{tabular}{|c|c|c|c|c|c|c|c|c|c|c|c|}
\hline \multirow{2}{*}{ Landuse } & \multirow{2}{*}{$\begin{array}{l}\text { Hor. } \\
\text { Soils }\end{array}$} & \multirow{2}{*}{$\begin{array}{c}\text { depth } \\
(\mathrm{cm})\end{array}$} & \multirow{2}{*}{$\begin{array}{c}\begin{array}{c}\text { C- } \\
\text { org. }\end{array} \\
\%\end{array}$} & \multicolumn{2}{|c|}{$\mathrm{pH}$} & \multirow{2}{*}{ Classification } & Sand & Loam & Rough & Smooth & \multirow{2}{*}{ Texture } \\
\hline & & & & $\mathrm{H}_{2} \mathrm{O}$ & $\mathrm{KCl}$ & & \multicolumn{4}{|c|}{.$(\%)$} & \\
\hline \multirow{4}{*}{ Forestry } & Ao & $0-15$ & 12.9 & 4.0 & 4.0 & Very acid & 38.4 & 15.1 & 7.6 & 38.9 & Sand clay \\
\hline & A1 & $15-30$ & 3.8 & 4.8 & 4.7 & Acid & 45.5 & 26.8 & 6.7 & 20.9 & Sand clay \\
\hline & B1 & $30-110$ & 3.3 & 4.8 & 4.8 & Acid & 30.6 & 24.2 & 9.8 & 35.4 & Sand clay \\
\hline & B2 & $110-150$ & 0.8 & 4.5 & 4.5 & Acid & & & & & \\
\hline \multirow{4}{*}{ Agroforestry } & Ap & $0-15$ & 2.2 & 4.2 & 4.2 & Very acid & 17.1 & 46.9 & 12.6 & 23.4 & Loam clay \\
\hline & A2 & $15-40$ & 0.3 & 4.5 & 4.5 & Acid & 23.5 & 48.4 & 9.5 & 18.6 & Loam sand \\
\hline & B1 & $40-70$ & 0.1 & 4.4 & 4.4 & Very acid & 20.6 & 47.3 & 9.7 & 22.4 & Loam clay \\
\hline & $\mathrm{B} 2$ & $70-100$ & 0.2 & 4.3 & 4.3 & Very acid & & & & & \\
\hline \multirow{4}{*}{$\begin{array}{c}\text { Dryland } \\
\text { agriculture }\end{array}$} & Ap & $0-25$ & 4,2 & 4.4 & 4.4 & Very acid & 46.6 & 25.4 & 2.2 & 25.8 & Sand clay \\
\hline & $\mathrm{A} 2$ & $25-50$ & 4.1 & 4.7 & 4.7 & Acid & 22.4 & 45.8 & 13.8 & 18.1 & Loam sand \\
\hline & B1 & $50-75$ & 1.6 & 4.7 & 4.7 & Acid & 11.1 & 55.8 & 18.1 & 15.1 & Loam clay \\
\hline & B2 & $75-110$ & 0.6 & 4.3 & 4.3 & Very acid & & & & & \\
\hline
\end{tabular}

\subsection{Sequential Extraction of Iron}

Mean concentrations of $\mathrm{Fe}$ fractions in the forested, agro-forested, and dryland agricultural

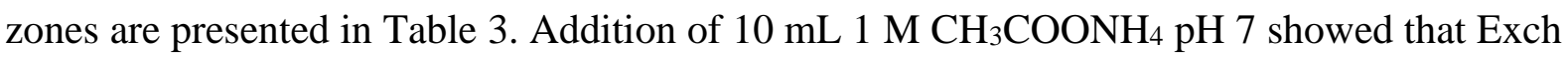
Fe concentrations in the forested and dryland agricultural soils decreased with depth of the soil horizon, contrary to the agro-forested land. Exch Fe fraction was the form of Fe available for plants. Dryland agriculture had a higher Exch Fe than the forested and agro-forested because the main component of the soil was dominated by clay minerals (Table 2). Based on the criteria of Fe availability in the soil, exchangeable Fe concentration in the agro-forested land was very high, medium to very high in the forested land, and relatively low in the dryland agriculture (Eviati \& Sulaiman, 2009). According to Mandal, Basu, Roy, Sheeja, \& 
Roy (2004), lowland acidic soils, swampland, coastal swamps, ultisol, and irrigated oxisol soil type often experience Fe toxicity. Fractions can be exchangeable, indicating the availability index of an element in the soil. Distribution of Fe in the forested land decreased with depth of the soil horizon, while there was an accumulation on the subsurface horizon of the agro-forested land. Fe was evenly distributed through the subsurface of the dryland agriculture.

Table 3. Mean of the fraction of Fe in the forested, agro-forested, and dryland agricultural soils $(\mathrm{ppm})^{*}$

\begin{tabular}{|c|c|c|c|c|c|c|c|c|c|c|c|c|}
\hline \multirow[b]{2}{*}{ Landuse } & \multirow{2}{*}{$\begin{array}{l}\text { Hor. } \\
\text { Soils }\end{array}$} & \multirow{2}{*}{$\begin{array}{l}\text { depth } \\
(\mathrm{cm})\end{array}$} & \multicolumn{10}{|c|}{ The mean of $\mathrm{Fe}$ fractions } \\
\hline & & & $\begin{array}{l}\text { Exch } \\
\text { Fe }\end{array}$ & $\%$ & $\begin{array}{c}\text { Acex } \\
\text { Fe }\end{array}$ & $\%$ & $\begin{array}{l}\text { Red } \\
\text { Fe }\end{array}$ & $\%$ & Oxz Fe & $\%$ & Res Fe & $\%$ \\
\hline \multirow{4}{*}{ Forestry } & Ao & $0-15$ & 5.3 & 0.018 & 19.4 & 0.064 & 385.8 & 1.30 & 6738.2 & 22.3 & 23000.8 & 76.3 \\
\hline & A1 & $15-30$ & 3.4 & 0.010 & 17.8 & 0.051 & 718.5 & 2.00 & 3616.9 & 10.3 & 30719.3 & 87.6 \\
\hline & B1 & $30-110$ & 4.8 & 0.006 & 16.1 & 0.022 & 954 & 1.30 & 7351.7 & 9.9 & 66075 & 88.8 \\
\hline & B2 & $110-150$ & 2.9 & 0.004 & 18.7 & 0.028 & 1326 & 2.00 & 11596.8 & 17.5 & 53482.3 & 80.5 \\
\hline \multirow{4}{*}{ Agroforestry } & Ap & $0-15$ & 4.3 & 0.005 & 12.5 & 0.13 & 580.2 & 0.60 & 7081.6 & 7.6 & 85550 & 91.8 \\
\hline & $\mathrm{Ab}$ & $15-40$ & 3.2 & 0.007 & 22.1 & 0.048 & 828.8 & 1.80 & 5620.9 & 12.1 & 40025.9 & 86.1 \\
\hline & B1 & $40-70$ & 4.3 & 0.006 & 13 & 0.019 & 694.5 & 1.00 & 4494.4 & 6.7 & 61993.5 & 92.3 \\
\hline & B2 & $70-100$ & 12.2 & 0.022 & 13.5 & 0.024 & 681.4 & 1.20 & 3603.4 & 6.4 & 51918.5 & 92.3 \\
\hline \multirow{4}{*}{$\begin{array}{l}\text { Dryland } \\
\text { agriculture }\end{array}$} & Ap & $0-25$ & 3.1 & 0.008 & 17.2 & 0.045 & 738.5 & 2.00 & 1757.5 & 4.6 & 35318 & 93.3 \\
\hline & $\mathrm{Ab}$ & $25-50$ & 6.3 & 0.022 & 20.5 & 0,072 & 999.8 & 3.50 & 6970 & 24.5 & 20427.9 & 71.9 \\
\hline & B1 & $50-75$ & 4.3 & 0.007 & 13.5 & 0.023 & 1248.8 & 2.10 & 2029.5 & 3.4 & 56392.8 & 94.5 \\
\hline & B2 & $75-110$ & 3.5 & 0.009 & 19.8 & 0.052 & 1182.2 & 3.10 & 2953.1 & 7.7 & 33994.5 & 89.1 \\
\hline
\end{tabular}

*Description: Ao = horizon dominated by organic matter; A1 = horizon with an accumulation of fine organic matter mixed with mineral materials and not dominated by the $\mathrm{E}$ or $\mathrm{B}$ horizon; $\mathrm{B} 1=$ horizon formed under $\mathrm{A}, \mathrm{E}$, or $\mathrm{O}$, or the intermediate horizon where the parent material is still visible; $\mathrm{B} 2=$ the maximum/transition accumulation horizon from $\mathrm{B}$ to $\mathrm{C}$ or $\mathrm{R}$, with an illustration of clay, $\mathrm{Fe}, \mathrm{Al}$, hummus, carbonate, or a combination of these; Exch= Exchangeable; Acex= Acid extractable; Red= Reducible; Oxz= Oxidizable; Res= Residual; Exch= Exchangeable; Acex= Acid extractable; Red= Reducible; Oxz= Oxidizable; Res= Residual

Acid extractable fractions (Acex Fe) showed a greater increase than the Exch Fe fraction; distribution was relatively uniform Acex Fe concentration in each soil horizon and land use. Forested Acex Fe concentration was around 16\%-19.4\%, agro-forested around 12\%-22.1\%, and dryland agricultural around $13 \%-20.5 \%$. Addition of sodium acetate $\left(\mathrm{CH}_{3} \mathrm{COONa}\right) \mathrm{pH} 5$ (Acex $\mathrm{Fe}$ ) caused $\mathrm{H}^{+}$ions to increase, so that $\mathrm{Fe}^{3+}$ ions in the soil were free to produce metal forms that bonded to carbonate (Tessier et al., 1979) under acidic conditions, forming strong oxides and hydroxyapatite (Abollino et al., 2006). Low molecular weight of the organic acids contributed to Fe translocation in the podzolization process (Xue, Seip, Guo, Liao, \& Zeng, 2006). Acex Fe fraction and Exch Fe was highly available in metal form for plant absorption. Each field showed a very low percentage $(<1 \%)$ of Exch Fe and Acex Fe since Fe forms very strong oxide and hydroxyapatite. 


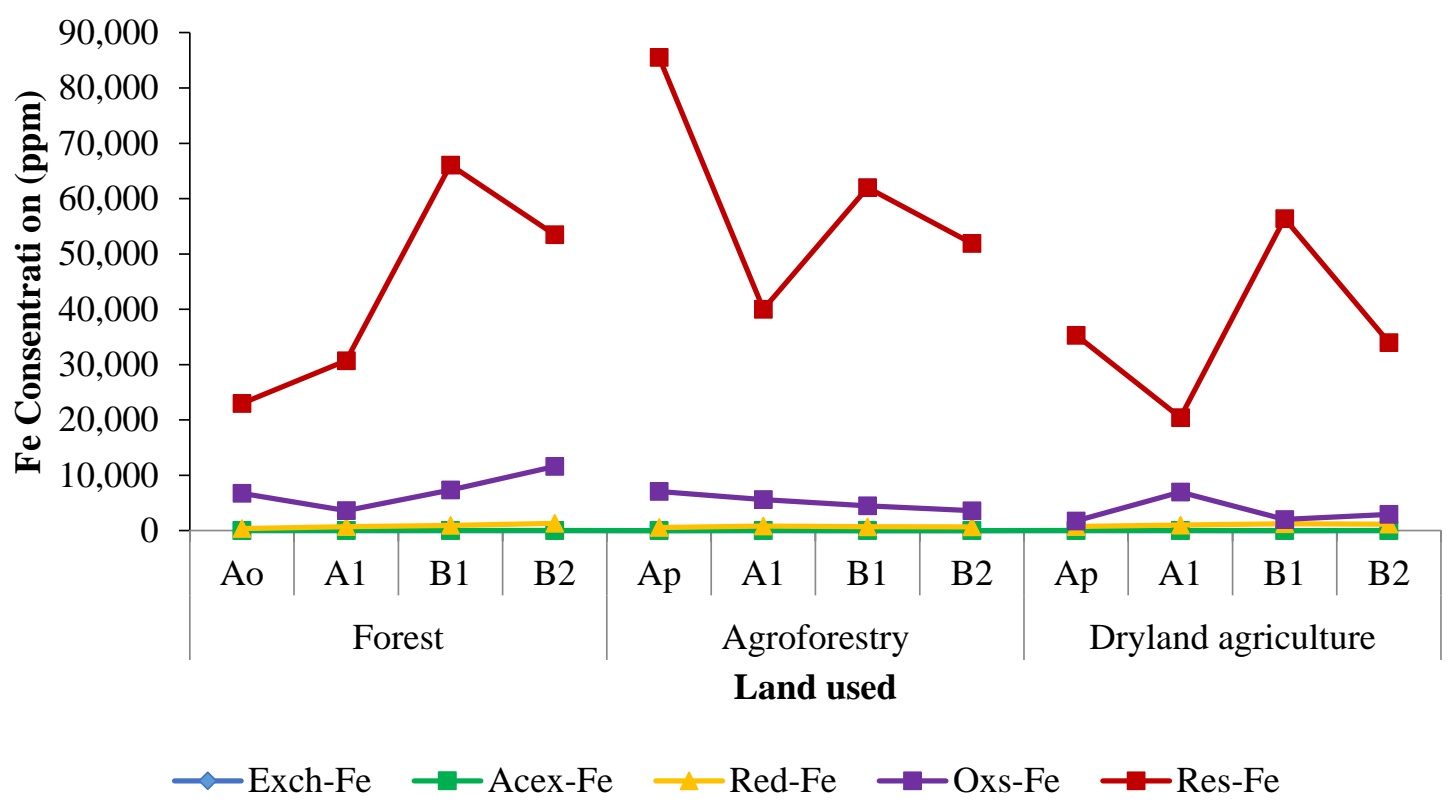

Figure 1. Distribution of Fe fraction in forested, agro-forested, and dryland agricultural soils

Addition of hydroxylamine hydrochloride in acetic acid at $96^{\circ} \mathrm{C}$ for $5 \mathrm{hr}$ aimed to incite oxide formation in the reducible fractions (Red $\mathrm{Fe}$ ). Concentration of Red $\mathrm{Fe}$ was significantly higher than Exch Fe and Acex Fe fractions in each field. Concentrations of Red Fe were relatively similar in each horizon and land use with a distribution pattern increasing with depth of the soil. This resulted from the lower levels of amorphous mineral dissolution and crystal mineral oxides (Abollino et al., 2006). The dryland agriculture had a reduced Fe concentration of around 738-1248 ppm, the forested land around 385-1326 ppm, and the agro-forested land around 580-828 ppm.

Oxidizable fractions (Oxs) are fractions whose availability is detrimental to plants (Tessier et al., 1979). Oxs Fe concentrations in the forested land, by percentage, increased significantly to around $9 \%-22 \%$, in the agroforestry to around $6 \%-12 \%$, and in the dryland agriculture to around 3\%-24\%. Distribution of Oxs Fe decreased with soil depth in the agroforested land, in contrast to the forested land and dryland agricultural. Soil fraction showed that Oxs Fe concentration in the soil horizon dominated by sand was higher than that in the soil horizon containing only a small amount of clay (Walna et al., 2010). Soil extract in very acidic conditions ( $\mathrm{pH}$ 2) decomposed, as completely as possible, organic matter that was still attached to various mineral components of the soil, not only in the mineralization of organic compounds, but also in the release of metals from the space between the layers of clay minerals and decomposed aluminosilicate (Popovic, Djodjevic, \& Polic, 2003 and Tessier et al., 1979). Availability of organic matter in the soil and soil texture affects the distribution of $\mathrm{Fe}$ in the soil. Fe toxicity occurs only in stagnant mineral soils for long periods. This is caused by $\mathrm{Fe}^{3+}$ becoming $\mathrm{Fe}^{2+}$, with concentrations that can exceed $1000 \mathrm{mg}^{-1}$ so that the soil is more soluble in water (Kirk, 2004). Soil fractions dominated by sand show higher concentrations of Fe-oxidized than horizons containing small amounts of clay (Walna et al., 2010). 


\subsection{Sequential Extraction of Manganese}

Distribution of Mn fractions in all land uses and soil horizons is presented in Table 4 and Figure 1. Exch Mn content was much higher than the Exch Fe fraction, around 4-97 ppm in the forest, around 20-96 ppm in the agro-forest, and around 1-33 ppm in the dryland agricultural. Percentages showed that the availability of Exch Mn in the agro-forested land was higher than that in the forested and dryland agricultural lands, with a decreasing distribution with soil depth. Percentage of Exch Mn in the forested land ranged from $1.5 \%$ in the Ao horizon to $0.2 \%$ in the B2 horizon; in the agro-forested land, from $3.1 \%$ in the forested zone to $0.9 \%$ in the B2 horizon, while in the dryland agriculture, it decreased from $0.8 \%$ in the Ao horizon to $0.01 \%$ in the $\mathrm{B} 2$ horizon.

Concentration of Acex Mn was higher than that of Exch Mn in every field, with the same distribution as Acex Fe, and decreased with soil horizon level. Mean concentrations of Acex $\mathrm{Mn}$ in the forested land was around $23-116 \mathrm{ppm}$, in the agro-forested, around 22-135 ppm, and in the dryland agricultural, around 16-72 ppm. Mn toxicity affects plants starting at around 400-500 ppm, so that, in the research area, Mn had no such effect. Distribution patterns showed significant differences in Mn content in the surface horizon, with the lowest horizon in each field. High Mn in the surface horizons was related to the content of C-organic and litter (Walna et al., 2010), as well as weak Mn binding properties in organic matter (Xue et al., 2006).

Table 4. Means of Mn fractions in forested, agro-forested, and dryland agricultural lands $(\mathrm{ppm})^{*}$

\begin{tabular}{|c|c|c|c|c|c|c|c|c|c|c|c|c|}
\hline \multirow[b]{2}{*}{ Landuse } & \multirow{2}{*}{$\begin{array}{l}\text { Hor. } \\
\text { Soils }\end{array}$} & \multirow[b]{2}{*}{ Depth $(\mathrm{cm})$} & \multicolumn{10}{|c|}{ The mean of Mn fractions } \\
\hline & & & $\begin{array}{c}\text { Exch } \\
\text { Mn }\end{array}$ & $\%$ & $\begin{array}{c}\text { Acex } \\
\text { Mn }\end{array}$ & $\%$ & $\begin{array}{l}\text { Red } \\
\text { Mn }\end{array}$ & $\%$ & $\begin{array}{l}\text { Oxz } \\
\mathrm{Mn}\end{array}$ & $\%$ & $\begin{array}{l}\text { Res } \\
\text { Mn }\end{array}$ & $\%$ \\
\hline \multirow{4}{*}{ Forestry } & Ao & $0-15$ & 97.2 & 1.50 & 116.4 & 1.8 & 837.4 & 13.0 & 4657.4 & 72.0 & 757.1 & 11.7 \\
\hline & $\mathrm{A} 1$ & $15-30$ & 19.8 & 0.47 & 34.9 & 0.8 & 1105.6 & 26.1 & 2531.2 & 59.7 & 547.8 & 12.9 \\
\hline & B1 & $30-110$ & 4.8 & 0.11 & 23.7 & 0.5 & 873.0 & 19.5 & 2467.1 & 55.2 & 1100.3 & 24.6 \\
\hline & B2 & $110-150$ & 13.2 & 0.24 & 37.9 & 0.7 & 817.8 & 14.9 & 3806.8 & 69.4 & 811.6 & 14.8 \\
\hline \multirow{4}{*}{ Agroforestry } & Ap & $0-15$ & 96.7 & 3.11 & 135.5 & 4.4 & 440.6 & 14.2 & 1642.9 & 52.9 & 788.8 & 25.4 \\
\hline & A2 & $15-40$ & 61.7 & 2.21 & 104.0 & 3.7 & 428.3 & 15.3 & 1609.7 & 57.5 & 595.7 & 21.3 \\
\hline & B1 & $40-70$ & 20.6 & 0.99 & 23.7 & 1.1 & 281.6 & 13.6 & 1113.0 & 53.6 & 635.7 & 30.6 \\
\hline & B2 & $70-100$ & 21.7 & 0.91 & 22.6 & 0.9 & 285.6 & 12.0 & 1397.2 & 58.6 & 655.3 & 27.5 \\
\hline \multirow{4}{*}{$\begin{array}{c}\text { Dryland } \\
\text { agriculture }\end{array}$} & Ap & $0-25$ & 33.1 & 0.76 & 72.0 & 1.7 & 1024.5 & 23.6 & 2280.9 & 52.5 & 933.5 & 21.5 \\
\hline & $\mathrm{A} 2$ & $25-50$ & 3.7 & 0.11 & 22.9 & 0.7 & 902.5 & 27.6 & 1918.3 & 58.6 & 424.4 & 13.0 \\
\hline & B1 & $50-75$ & 1.0 & 0.02 & 16.6 & 0.3 & 1371.9 & 22.5 & 1904.5 & 31.3 & 2798.3 & 45.9 \\
\hline & B2 & $75-110$ & 1.1 & 0.02 & 23.2 & 0.5 & 1298.5 & 27.6 & 1574.0 & 33.5 & 1807.4 & 38.4 \\
\hline
\end{tabular}

*Description: Ao $=$ horizon dominated by organic matter; A1 = horizon with accumulations of fine organic matter mixed with mineral materials not dominated by the $\mathrm{E}$ or $\mathrm{B}$ horizon; $\mathrm{B} 1=$ horizon formed under A, E, or O, or the intermediate horizon where the parent material is still visible; B2 = the maximum/transition accumulation horizon from $\mathrm{B}$ to $\mathrm{C}$ or $\mathrm{R}$, with an illustration of clay, $\mathrm{Fe}, \mathrm{Al}$, hummus, carbonate, or a combination of these; Exch= Exchangeable; Acex= Acid extractable; Red= Reducible; Oxz= Oxidizable; Res= Residual. 


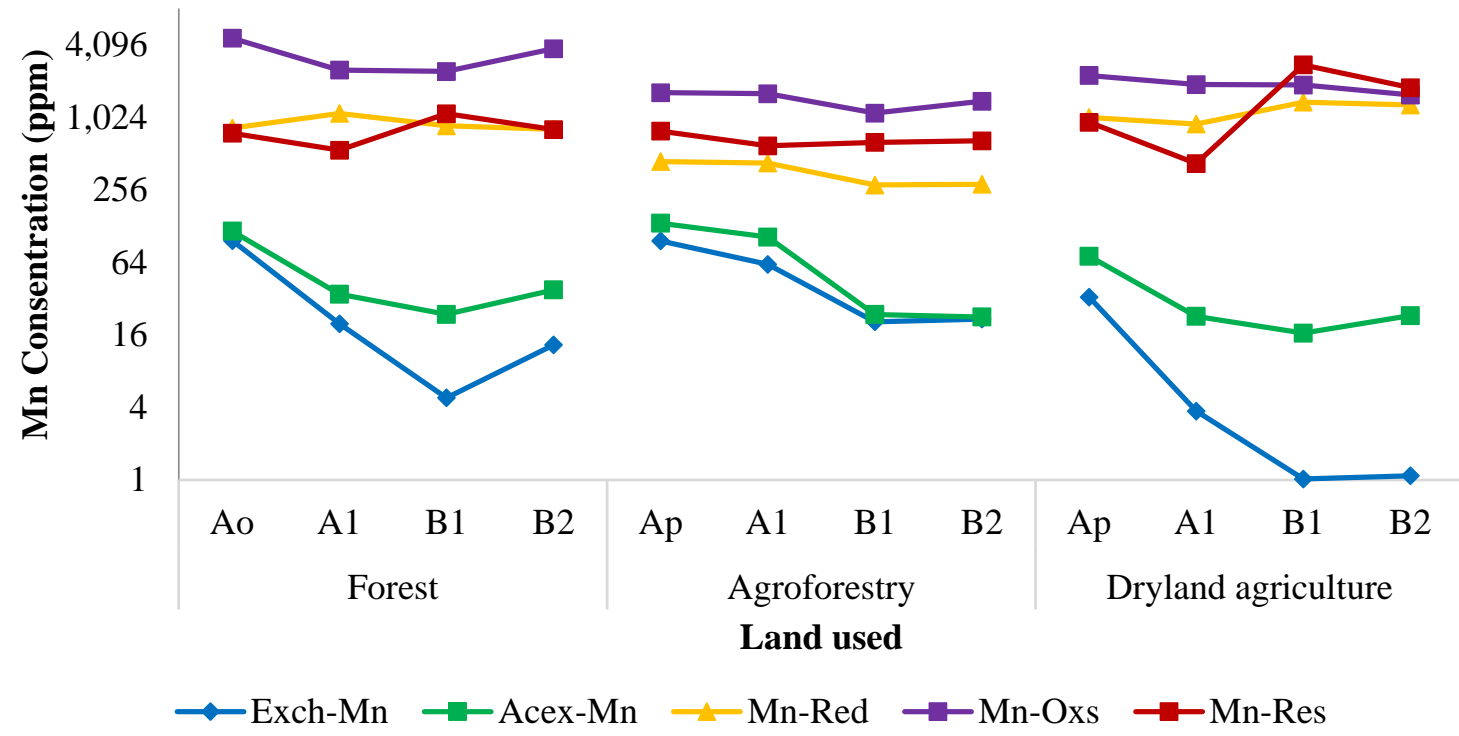

Figure 2. Distribution of Mn fractions in forested, agro-forested, and dryland agricultural soils

In the reducible fraction, most of the Mn oxide occurred due to very reductive conditions in very acidic pHs. The oxidizable fraction bound to Fe-Mn was most important for Mn, and extracted sufficient amounts of $\mathrm{Cd}, \mathrm{Pb}$, and $\mathrm{Zn}$. Results showed that the concentration of Red $\mathrm{Mn}$ in the forest soils increased from $13 \%$ in the Ao horizon to $19 \%$ in the B horizon, while upland, it increased from $23.6 \%$ in the Ap horizon to $27.0 \%$ in the B2 horizon. However, the concentration of Red Mn in the dryland agriculture decreased from 14\% in the Ap horizon to $12.0 \%$ in the B2 horizon. This was because most Mn oxides occur in very reductive conditions at very acidic pHs. The same results were shown by Sanchez et al. (2005), Wang et al. (2008), and Navas and Lindhorfer (2005), with a percentage of Red Mn $<60 \%$.

Results of the analysis showed that the concentration of Oxs Mn fraction was higher in the forest soils than in the dryland agricultural and agro-forest ones. Distribution decreased with soil depth in the forest and dryland agricultural soils, but increased with depth in the agro-forested ones. In the forested soil, which was dominated by sandy texture, distribution decreased from about $72 \%$ in the surface horizon to $55 \%$ in the subsoil. In the agro-forested soil, which was dominated by a clay texture, Mn-oxidation was evenly distributed at around $52 \%-58 \%$ through each soil horizon. Distribution of Mn oxide in the dryland agricultural and forested soils was about $52 \%$ in the surface horizon and $33 \%$ in the subsurface horizon. The percentage of Res Mn fraction was around $11 \%-14 \%$ in the forested soils, around $21 \%-30 \%$ in the agro-forested soils, and around $13 \%-45 \%$ in the dryland agricultural soils. Results of the same study conducted by Walna et al. (2010) revealed that about $12 \%-41 \%$ of the Res Mn fraction could be extracted. The authors (2010) stated that the level of metal mobility in the soil, based on its tight binding to soil components, was the same at each soil horizon. Residual fractions are considered the most stable crystals and are not available to plants (Tessier et al., 1979 and Wang et al., 2008). Except for these fractions, mobility of fractions can be calculated from their numbers (Sutherland, 2002). The normal limit of $\mathrm{Mn}$ in soils is 20-10,000 ppm, and the critical limit, around 1500-3000 ppm; in plants, the normal limit is 20-1000 ppm, and the critical limit, around 100-7000 ppm (Eviati \& Sulaiman, 2009). 


\section{Conclusion}

The average total concentration of Fe, in declining order, is agro-forested soils $>$ forested $>$ dryland agriculture, with distribution increasing with depth of soil horizon in each land use, except for agroforestry. Highest Exch Fe concentration in agro-forested soils is around 4.3 ppm at the Ap horizon, increasing to $12.2 \mathrm{ppm}$ at the B2 horizon; in dryland agricultural soils, it is around $3.1 \mathrm{ppm}$ at the Ap horizon, increasing to $3.5 \mathrm{ppm}$ at the B2 horizon; in forested soils, it decreases from $5.3 \mathrm{ppm}$ at the Ao horizon to $2.9 \mathrm{ppm}$ at the B2 horizon. For $\mathrm{Mn}$, average total concentration, in declining order, is forested soils > dryland agricultural > agro-forested, with average distribution decreasing with depth of soil horizon in each land use. Highest Exch Mn concentration in agro-forested soils is around $50.2 \mathrm{ppm}$, in forested, around $33.8 \mathrm{ppm}$, and in dryland agricultural, around $9.7 \mathrm{ppm}$.

\section{Acknowledgements}

Thanks to KEMENRISTEKDIKTI for the Indonesian Lecturer Superior Scholarship program (BUDI-DN Affirm), the Regional Government of Merauke Regency and Musamus University (UNMUS).

\section{References}

Abollino, O., Giacomino, A., Malandrino, M., Menthasi, E., Aceto, M., \& Barberis, R. (2006). Assessment of Metal Availability in Contaminated Soil by Sequential Extraction. Water, Air, and Soil Pollution, 137, 315-338. https://doi.org/10.1007/s11270-005-9006-9

Celik, H., Asik, B. B., Gurel, S., \& Katkat, A. V. (2010). Effect of Potassium and Iron on Macro Element Uptake of Maize. The Journal of Zemdirbyste Agriculture, 97(1), 11-22. Retrieved from https://www.cabdirect.org/cabdirect/abstract/20103160065

Dubikova, M., Cambier, P., Sucha, V., \& Caplovicova, M. (2002). Experimental in Soil Acidification. Applied Geochemistry, 17, 245-257. https://doi.org/10.1016/S08832927(01)00081-6

Eviati, \& Sulaiman. (2009). Analysis of Soil, Plants, Water and Fertilizers Chemical (Analisis Kimia Tanah, Tanaman, Air, dan Pupuk). Bogor: Balai Penelitian Tanah.

Ghiorse, W. C. (1978). Microbial Reduction of Manganese and Iron in Biology of Anaerobic Microorganism Edited by Zehnder. New York, US: John Wiley \& Sons, Inc.

Kirk, G. (2004). The Biogeochemistry of Submerged Soils. Chichester, UK: John Wiley \& Sons, Ltd.

Mandal, A. B., Basu, A. K., Roy, B., Sheeja, T. E., \& Roy, T. (2004). Genetic Management For Increased Tolerance to Aluminium and Iron Toxicities in Rice-A review. Indian Journal of Biotechnology, 3, 359-368. Retrieved from http://nopr.niscair.res.in/handle/123456789/5867

Mehraban, P., Ahmad, A. Z., \& Hamid, R. S. (2008). Iron Toxicity in Rice (Oryza sativa L.), Under Different Potassium Nutrition. Asian Journal of Plant Sciences, 7(3), 251-259. https://doi.org/10.3923/ajps.2008.251.259

Navas, A., \& Lindhorfer, H. (2005). Chemical Partitioning of Fe, Mn, Zn, Cr in Mountain Soils of the Iberian and Pyrenean Ranges (NE Spain). Soil and Sediment Contamination: An International Journal, 14(3), 249-259. https://doi.org/10.1080/15320380590928311 
Popovic, A., Djodjevic, D., \& Polic, P. (2003). Intraphase Correlations of Concentrations Obtained by Sequential Extraction of Nikola Tesla a Plant Coal Ash. In: Proceedings of The First International Conference on Environmental Research and Assessment, Bucharest, Romania, 23-37 March 2003.

Russel, E. W., \& Sir, E. J. R. (1973). Soil Conditions and Plant Growth. London: John Wiley $\&$ Sons, Inc.

Sanchez, D. M., Queido, A. J., Fernandez, M., Hernandez, C., Schmid, T., Millan, R., Gonzalez, M., Aldea, M., Martin, R., \& Morante, R. (2005). Mercury and Trace Element Fractionation in Almaden Soils by Application of Different Sequential Extraction Procedures. Analytical and Bioanalytical Chemistry, 381(8), 1507-1513. https://doi.org/10.1007/s00216-0053058-y

Segalen, P. (1971). Metallic Oxides and Hydroxides in Soil Warm and Humid Area of The World: Formation, Identification, Evolution. In Eswaran, D.H. Soils and Tropical Weathering. Unesco. Paris, FR.

Sutherland, R. A. (2002). Comparison Between Non-Residual Al, Co, Cu, Fe, Mn, Ni, Pb and Zn Released by a Three-step Sequential Extraction Procedure and a Dilute Hydrochloric Acid Leach for Soil and Road Deposited Sediment. Applied Geochemistry, 17(4), 353365. https://doi.org/10.1016/S0883-2927(01)00095-6

Tessier, A., Campbell, P. G. C., \& Bisson, M. (1979). Sequential Extraction Procedure for the Speciation of Particulate Trace Metals. Analytical Chemistry, 51(7), 844-851. https://doi.org/10.1021/ac50043a017

Walna, B., Spychalski, W., \& Ibragimow, A. (2010). Fractionation of Iron and Manganese in the Horizons of a Nutrient-Poor Forest Soil Profile Using The Sequential Extraction Method. Polish Journal of Environmental Studies, 19(5), 1029-1037. Retrieved from http://www.pjoes.com/Fractionation-of-Iron-and-Manganese-r-nin-the-Horizons-of-aNutrient-Poor-Forest,88479,0,2.html

Wang, X., Liu, Y., Zeng, G., Chai, L., Xiao, X., Song, X., \& Min, Z. (2008). Pedological Characteristics of $\mathrm{Mn}$ Mine Tailings and Metal Accumulation by Native Plants. Chemosphere, 72(9), 1260-1266. https://doi.org/10.1016/j.chemosphere.2008.05.001

Xue, N., Seip, H. M., Guo, J., Liao, B., \& Zeng, Q. (2006). Distribution of Al, Fe, Mn Pools and Their Correlation in Soils From Two Acid Deposition Small Catchments in Hunan, China. Chemosphere, 65(11), 2468-2476. https://doi.org/10.1016/j.chemosphere.2006.04.045 